Article

\title{
Unreliability and the Animal Narrator in Richard Adams's The Plague Dogs
}

\section{Anja Höing}

Institute of English and American Studies, University of Osnabrück, 49074 Osnabrück, Germany; ahoeing@uos.de

Academic Editor: Joela Jacobs

Received: 20 December 2016; Accepted: 6 March 2017; Published: 8 March 2017

\begin{abstract}
Richard Adams's talking animal story The Plague Dogs (1978), with its deeply genre-atypical mode of narration, offers a multiplicity of avenues to explore the literary animal as animal. The story draws much of its power from the psychological complexity and related unreliability of both canine narrators, two research lab escapees gone feral. Both the terrier Snitter and the black mongrel Rowf are mentally ill and experience a highly subjective, part-fantastic world. In episodes of zero focalization, a sarcastic voice comments on the plot from the off, aggressively attacking a thoroughly anthropocentric superstructure the protagonists themselves are oblivious of, and presenting all that is normally constructed as "rational" in the implied reader's world as a carnivalesque farce. Combining these equally unreliable narratives, The Plague Dogs creates a unique mixture of what Phelan (2007) calls "estranging" and "bonding" unreliability and brings to light the devastating consequences of anthropocentrism. The Plague Dogs not only defamiliarizes a genre usually committed to conventional means of storytelling, but the dominant Western conception of the status of animals in the world, showing that once we start to read the animal as animal, this sets into motion an avalanche of other concepts in need of re-reading, among them the very ones making up the fundamental pillars of Western societies' anthropocentric self-conception.
\end{abstract}

Keywords: The Plague Dogs; Richard Adams; narratology; anthropocentrism; unreliability; talking animal stories; discourse analysis; non-human focalizer; Pincher Martin

\section{Introduction}

In 1972, British author Richard Adams made top of the bestseller lists with his talking animal story Watership Down (1972), a light-hearted rabbit Odyssey that has since become a classic. His second talking animal story, The Plague Dogs (1978) [1], in contrast, attracted little public notice and even less scholarly attention ${ }^{1}$ - despite the fact that Adams himself considers it his best novel [6]. This lack of interest might be due to the novel's far-reaching aspirations and weighty ideological agenda:

1 As yet, there are hardly any academic studies specifically dealing with Adams's dog novel. To my knowledge, David Collado Rodriguez's review "Beyond Satire: Richard Adams's The Plague Dogs" (1988) provides the only existing overview of all major topics and motifs of the story. The Plague Dogs also finds mention in articles primarily dealing with resistance to animal experimentation, especially ones published shortly after Adams's book. In a briefing on the topic "A New Militancy in England," for example, Nicholas Wade lists The Plague Dogs as a major example of support to the animal rights movement by "public figures" ([2], p. 279), while a brief in The Hastings Center Report remarks on the way novels such as The Plague Dogs alienate proponents of animal research ([3], p. 3). The Plague Dogs also tends to be mentioned in passing in works on animals in literature, such as Theodore Ziolkowski's Varieties of Literary Problematics ([4], p. 95), or in works on fantasy, e.g., in Colin Manlove's The Fantasy Literature of England ([5], p. 61). Manlove, however, discusses The Plague Dogs under the premise that "two [bubonic plague] infected dogs escape a research station and become a danger to human society" ([5], p. 61), while, in fact, the entire point of Adams's tale is that the dogs are not infected at all, cannot be infected, because the lab was properly secured and additionally instinct warned them to keep off ([1], p. 30). Human society and its media hysteria becomes a danger to the dogs, not the other way round. 
The Plague Dogs is a stylistically complex and deeply disturbing story addressing animal rights and animal subjectivity—an openly political text that, unlike most other talking animal stories, does not invite the reader into a suspenseful yet beautiful secondary world of talking animals, but lays open the injustices and cruelties animals have to face in a thoroughly anthropocentric world.

The main plotline of The Plague Dogs can be told in a few words. Two dogs, the terrier Snitter and the black mongrel Rowf, escape an animal research lab and aimlessly wander the inhospitable wilderness of the English Lake District national park. A media hype blossoms around a newspaper's fabricated allegation that the research station escapees are infected with bubonic plague. This triggers a snowball effect of scientists fighting to shift the blame, politicians struggling to keep face, and newspapers trying to raise circulation by further blowing up the story, which finally ends in a witch hunt for the innocent dogs. At the very second of their imminent deaths, however, the two dogs are miraculously saved by caring humans.

The story makes use of complex symbolism, combining elements from Carl Gustav Jung's archetypes of the collective unconscious [7] and Joseph Campbell's stages of a hero's quest as proposed in The Hero with a Thousand Faces [8]. In addition to this, much of the complexity and intensity of The Plague Dogs derives from the novel's unusual narrative mode. The Plague Dogs is, in Theodore Ziolkowski's words, a "cynomorphic" ([4], p. 95) novel, as in parts it is narrated "from the dog's point of view" ([4], p. 95). The story is told from a multiplicity of perspectives, most notably Snitter's, but also Rowf's, the scientists', the newspaper journalist's, etc. Yet every single one in this cacophony of focalizers is unreliable- the unreliability even extends to the voice of the heterodiegetic narrator, who keeps together all strands of narration. As a result, The Plague Dogs creates a unique mixture of what James Phelan (2007) calls "estranging" ([9], p. 223) and "bonding" ([9], p. 223) unreliability. This article aims to show how the unreliable narration of The Plague Dogs defamiliarizes a writing tradition usually committed to conventional means of storytelling, and in doing so calls into question the dominant Western conception of the status of animals in the world. Once we start to read the animal protagonist as animal, as The Plague Dogs forces its readers to do, this sets into motion an avalanche of other concepts in need of re-reading, among them the very ones that justify Western societies' anthropocentric self-conception and the according subjugation and exploitation of other species.

\section{Adapting a Non-Human Perspective toward Unreliability}

As yet, unreliability was hardly, if ever, discussed with respect to animal stories, yet it is an immensely useful tool to deconstruct stereotypical portrayals of literary animals and to force the reader to take animal narrators seriously. Originally proposed by Wayne C. Booth in his 1961 publication The Rhetoric of Fiction as a form of narration in which the narrator's "judgement is suspect" ([10], p. 174), unreliability was approached by a number of scholars who brought different conceptual backgrounds and perspectives to the discussion. This is no place to rehearse this complex theoretical discussion: for an up-to-date summary of the different positions and their contestants the reader may refer to Shen (2014) [11]. I will only briefly sketch the theoretical dimensions of unreliability that are most central to my line of argument.

Unreliability can roughly be defined as a feature of narratorial discourse in which the narrator "offers an account of some event, person, thought, thing, or other object in the narrative world that deviates from the account the implied author would offer" ([12], p. 49). Phelan (2005) identifies six kinds of unreliability: "misreporting, misreading, misevaluating—or what I will call misregarding —and underreporting, underreading, and underregarding" ([12], p. 51). As Shen points out, unreliability can occur either as a "clash between story and discourse" ([11], p. 898) -if the narrator misreports story elements-or as a clash "between the narrator's explicit discourse and the author's implicit discourse" ([11], p. 898) - if the narrator misreads, i.e., misinterprets, or misregards story elements. Phelan introduces a typology to analyze narratorial unreliability with a focus on its effect on the implied reader or "authorial audience" ([9], p. 223). Starting from the observation that different types of unreliable narration have distinctly different effects on the implied reader, Phelan differentiates unreliability 
into two groups. Unreliable narration can either "[underline] or [increase] the distance between the narrator and the authorial audience" ([9], p. 223), or, to the contrary, "[reduce] the distance between the narrator and the authorial audience" ([9], pp. 223-24). Phelan calls the former type of unreliability "estranging unreliability" ([9], p. 223), and the latter one "bonding unreliability" ([9], p. 223). Focussing on the latter, Phelan uses an exemplary discussion of Vladimir Nabokov's Lolita to identify and discuss six subtypes of bonding unreliability: (1) "literally unreliable but metaphorically reliable" ([9], p. 226); (2) "playful comparison between implied author and narrator" ([9], p. 228); (3) "naive defamiliarization" ([9], p. 229); (4) "sincere but misguided self-deprecation" ([9], p. 229); (5) "partial progress toward the norm" ([9], p. 231); and (6) "bonding through optimistic comparison" ([9], p. 232).

Unfortunately, unreliable narration has as yet predominantly been discussed in context with what Phelan calls "character narration" ([12], p. 1), i.e., the narration of what Gérard Genette calls a "homodiegeti[c]" ([13], p. 159) narrator, i.e., a narrator who is part of the world of the story's protagonists ([13], p. 159). The Plague Dogs, however, is a story predominantly told by a narrator that Genette would describe as "heterodiegeti[c]" ([13], p. 159), one that is hovering outside the protagonists' world ([13], p. 159). What is more, to unravel unreliability in The Plague Dogs one needs to look beyond the unreliability of the primary narrator to the unreliability of the focalizers and the canine protagonists who tell stories-inside-the-story. This creates a multi-layered net of unreliabilites that build and depend upon one another, while simultaneously being contradictive to the point of undermining even another narrative strand's allegedly reliable elements. I will move through this net in a rough bottom-up approach, starting at the dogs' unreliable perception of the world, before scrutinizing the heterodiegetic narrator. Finally, I will turn my attention to the controversial ending of The Plague Dogs, which leaves the reader a stranded victim of competing unreliabilities.

The story draws much of its power from the psychological complexity of the canine main protagonists and central focalizers, two research lab escapees gone feral. In consequence of the exceedingly cruel and completely pointless experiments conducted on them in the lab, both Snitter and Rowf are mentally ill and deeply traumatized. ${ }^{2}$ Snitter has undergone brain surgery that aimed at "bring[ing] about a confusion of the subjective and objective in the animal's mind" ([1], p. 227), and can no longer clearly distinguish between outside phenomena and his imagination. Rowf was subjected to survival conditioning experiments and repeatedly immersed into a tank of water until near-drowning, in order to, in the language of the scientists, identify "a point where the additional endurance induced by the dog's expectation of removal [from the tank] is counterbalanced by the limits of its physical capacity" ([1], p. 4). He shows typical symptoms of what in human psychology would be referred to as a post-traumatic stress disorder, is distrustful, unpredictably aggressive, and-for obvious reasons-mortally afraid of water. But not only their psychological disorders make the characters experience the world in a different way than the implied reader would-their animality does, too. Unlike the protagonists of many other talking animal stories, the animal heroes of The Plague Dogs are not metaphorical placeholders substituted for a human experience, although it is of course possible to read them in this way too, e.g., when endorsing the story's Jungian discourse. ${ }^{3}$ Yet, for the reading of the story I propose in this article, it is central to read the canine protagonists as, indeed, dogs, and as such as distinctively non-human focalizers. Snitter, for example, experiences "something out of the ordinary" as "some small alteration to the familiar as slight but disturbing as the discovery

2 This article cannot and will not contribute to the general debate on animal consciousness and the complex and ongoing discussion in how far other species are able to experience mental as well as physical suffering, and develop psychological trauma. Nonetheless I use (human) psychological vocabulary for a reason here. The implied author of The Plague Dogs clearly indicates that, in his eyes, dogs are conscious beings who are capable of suffering mental disorders just as humans do, and he creates his canine characters accordingly. Just as he renders the dogs' communication as direct speech in a human language, he translates their mental sufferings into dimensions the human reader can relate to, i.e., into human psychological disorders.

3 See for example, Collado Rodriguez's discussion of the psychological dimension of The Plague Dogs ([14], p. 53). 
of a stranger's urine against one's own garden fence" ([1], p. 21), and his world-as is typical for canines ([15], p. 80) - is primarily an olfactory and auditory, not a visual one.

The two dogs, baffled by human technologies and biased by an inherited sense of inferiority ([16], p. 70), frequently misinterpret and misregard natural phenomena or human behaviour. Snitter, chasing sheep, interprets an infuriated shepherd as "apparently yelling encouragement" ([1], p. 65), and his action as an act of "help" ([1], p. 96) that the human, for reasons the terrier cannot fathom, emphatically rejects. In this example, one can see that Phelan's terminology might be in need of adjustment when applied to animal focalizers. In the character-character-interaction between Snitter and the shepherd, Snitter's misinterpretation is not so much a consequence of narratorial unreliability as of narratorial otherness. His narration is based on a canine, not a human norm-and, with regard to the canine norm, he might not be misinterpreting the situation at all. Here, a species-related difference in stimulus interpretation creates a narratorial gap that in turn causes the (human) reader to classify Snitter's account as unreliable.

At another point Snitter, now as intradiegetic narrator of a story-inside-the-story, nostalgically reminiscences about his past blissful time as a bachelor's pet:

A long time ago, when there were towns-when there was a real world-I used to live with my master in his house. ... in the morning a boy used to come and stuff a lot of folded paper through a hole in the middle of the street-door downstairs. ... I used to go down and pick the paper up in my mouth and carry it upstairs and wake my master. ... and then we always played a kind of game with this wodge of paper. He used to open it up very wide... and spread it out in front of him while he sat up in bed, and I used to creep up the bed and poke my nose underneath. Then he used to pretend to be cross and pat it and I used to take it away and wait a bit and then poke it under somewhere else. I know it sounds silly, but I always thought how nice it was of him to get that boy to bring a fresh lot of paper every day, just so that we could play this game. ([1], pp. 177-78)

At a first glance, Snitter's autodiegetic account looks like the form of unreliable narration most characteristic to talking animal stories, an exclusively bonding form of "naive defamiliarization" ([9], p. 229), endearing the innocently mistaken dog to the implied reader. Yet there is also a much darker note to this story-inside-the-story. The beginning of Snitter's narrative, a common variation of "once upon a time," clearly denotes his story as a fairy tale, and thus calls into question the authenticity of all that comes after. The canine narrator does not only displace the idea of an intact inter-species friendship into the past, but into myth, into an idealized world that has dissolved into nothingness at the moment scientific rationalism severed the animal-human bond.

What remains for Snitter and Rowf is a belief in human omnipotence coupled with deep feelings of canine inferiority. They believe that humans terra-form the landscape ([1], p. 47), control the weather ([1], p. 312), put the sun in the sky and lightened it like a light bulb ([1], p. 48), and regularly mine the moon to turn its brightness into car headlights ([1], p. 257). Again, the dogs' naive defamiliarization is a bonding form of unreliability. More so, their observations are also metaphorically reliable. "[Humans] run the world for themselves" ([1], p. 284), Rowf concludes bleakly, "they don't care what they do to us; they just make use of us for their own convenience" ([1], p. 257). And, being omnipotent, they "could alter this [world] if they wanted" ([1], p. 257), yet they do not bother to. Although not as powerful as the dogs hold humans to be, there is certainly more than a grain of truth to Rowf's final conclusion. Animals, in turn, are there "to have things done to them by men" ([1], p. 47), in Rowf's assessment. Accordingly, he considers his escape from the lab as mutiny from his duty ([1], p. 97; see also [16], p. 71). Tellingly, Rowf even sees his canine god as inferior to mortal humans. In another story-inside-the-story, Rowf tells the legend of the canine deity, the "Star Dog" ([1], p. 136). The deity may have created the world, but he can neither boast the humans' fingers and opposable thumbs ([1], p. 137) nor is his simple and trusting canine mind a match for his two-legged creations' blatant arrogance and disobedience ([1], p. 140). Instead of a typical talking animal world with a happy ending guaranteed-the world of Snitter's innocent newspaper fairy 
tale-Rowf-as-narrator sketches a bleak world in which animals do not stand a chance against human preeminence. Rowf's Star Dog, in fact, inadvertently created not a fantastic, but a realistic space.

In both Snitter's newspaper story and Rowf's Star Dog story, the unreliability of the canine narrators is unambiguously of the bonding type. "The story-teller wishes us to identify with Snitter and Rowf and their sufferings" ([14], p. 51), as Collado Rodriguez remarks, and accordingly "uses a device which had already proved very successful in Watership Down: the narrator shows the external world from a dog's point of view" ([14], p. 51). This device is far from being unique to Adams's writings. Instead, one can claim similar instances of bonding unreliability to be a stock element of talking animal stories. The Plague Dogs, however, goes far beyond this type of narratorial unreliability. Typical talking animal story narration interplays with both the madness of the central focalizer Snitter and the erratic behaviour of the heterodiegetic narrator.

\section{Narrating without a Safety Net: A Canine Pincher Martin}

Most often, the narrator guides the reader's perception through the eyes of the terrier Snitter. Snitter is incapable of coping with the guilt of having caused the death of his master, and, additionally, has undergone experimental brain surgery that causes him to blur sensual perception with images conjured by his mind's eye. As an effect, his perception continually jumps between flashbacks of past—or imagined?-happiness, a nightmarish reality, and a surreal world constructed by his own imagination. Snitter has vivid hallucinations of his former master, who appears to him in reflections, or in dreams ([1], pp. 81, 165, 295, 356). Although Snitter is aware that these appearances are illusions, he cannot help but run after the familiar figure, hoping against hope that his master might really have miraculously reappeared.

Snitter starts to unconsciously reflect on these hallucinations in an encounter with a mysterious ghost dog. Awakened by a dog's bark and heading out into the night to search for its source, Snitter finds a "terrier bitch... whose appearance recalled others from the days of his old life with his master" ([1], p. 288). She turns out to be watching over the long-decayed corpse of her master, oblivious of his death. Although he is sure that she is another individual, he also immediately grasps her metaphorical dimension. In a Snitter-typical fit of madness he imagines a conversation with Rowf:

"Hullo, Snitter, are you all right?"

"Oh, yes, only there's two of me now! I split my head in two and made another dog! Here she is! Wuff wuff! Ho ho!" ([1], p. 289)

For Snitter, there is no contradiction in the ghost terrier being both a different individual and a part of himself-and, metaphorically, there is not. As Collado Rodriguez notes, "Adams is deeply influenced by Carl [Gustav] Jung" ([14], p. 52). His theory of the collective unconscious frequently provides a symbolic red thread the plot follows. This is reflected, for example, in Adams's frequent use of water, Jung's central symbol for the unconscious ([7], p. 28), as the story's guiding trope, or in the character of the tod, a messenger from an archetypal "ancestral force" ([14], p. 52). Yet Jung's theory makes its possibly strongest appearance in Snitter's encounter with the ghost bitch. The female terrier is, in fact, his anima. She is an archetypal force, a reflection of his soul ([7], p. 35), both frightening and attracting him, part-demonic ([7], p. 36) and, crucially, of the opposite gender. Jung describes the anima as "numinos" ([7], p. 37), i.e., numinous, and as such as both magical and dangerous, concerned with the taboos the consciousness tries to avoid dealing with ([7], p. 37). On his nightly excursion Snitter confronts his own unconscious: a loyal dog stubbornly guarding a human corpse, incapable of letting go of the illusion that her master will return. Snitter sees her predicament, deeply pities her, and finally even calls in her face, "Your master-your master is dead! He's dead!" ([1], p. 295). But the moment he starts to glimpse the truth—that it is his master he is talking about-Snitter panics. He draws back, suddenly seeing the ghost bitch as "a phantom, a nothing, a dried, empty husk of old grief suffered long ago" ([1], p. 295). When, seconds later, an apparition of his master appears, Snitter, none the wiser from his encounter with his anima, still denying reality, runs after him. In this 
scene, there is a deeply tragic twist to Snitter's unreliability. When Snitter appears to be unreliable, i.e., hallucinates, he is actually reliable - his hallucination is "literally unreliable but metaphorically reliable" ([9], p. 226), one of Phelan's criteria of bonding unreliability. Yet, when Snitter dismisses the hallucination and undergoes, in Phelan's terminology, a "partial progress toward the norm" ([9], p. 231), this does not establish a further bonding link, but estranges the reader, as in this moment Snitter bars his own progress towards realisation of his psychosis. In this scene, the two dimensions of bonding unreliability, Snitter's being "literally unreliable but metaphorically reliable" ([9], p. 226) and undergoing "partial progress towards the norm" ([9], p. 231), are incompatible. When Snitter's unrealiability is bonding in one of these categories, this automatically violates the other one and has an estranging effect with regard to this category, thus facing the implied reader with an unresolved conflict of competing unreliabilities.

The implied reader's awareness of Snitter's unreliability develops gradually. Although Snitter's mental illness never is in doubt, at first only his direct speech is unreliable, while he does not misreport to the reader or misinterpret story elements. When Snitter's reliable accounts start to become interspersed with hallucinations, the heterodiegetic narrator explicitly warns the reader ([1], p. 123) and Snitter himself, too, immediately classifies several of his experiences as unreliable. However, Snitter finally starts to call into question, and accordingly renders the implied reader suspicious of, accounts not only he himself previously perceived as reliable, but which the heterodiegetic narrator classifies as reliable through other focalizers as well, such as a fox hunt in which Snitter witnesses the tod's brutal death ([1], p. 390). At such moments, The Plague Dogs plays on an intertextual connection that runs through the story like a disturbing undercurrent, casting doubt onto the very nature of the dog focalizer's unreliability. Scientist Stephen Powell compares Snitter's mental condition to the one of William Golding's Pincher Martin, protagonist of the eponymous novel:

Er-well, did you ever read a book called Pincher Martin, by a man named Golding? You know, the Lord of the Flies bloke? ... Well, the chap in it's supposed to be dead... and in the next world, which is a sort of hellish limbo... He thinks he's still alive and that he's been washed up on a rock in the Atlantic, but actually it's an illusion and the rock is only a mental projection-it's the shape of a back tooth in his own head. The dog... might have illusions something like that. ([1], p. 227)

While Pincher Martin builds his perception of the imaginary island upon the image of a "tooth" ([17], p. 30), Snitter is preoccupied with the scar left by his brain operation. Repeatedly confusing his body with his environments, he perceives his surroundings as "both a product and the equivalent of his own mutilated mind" ([1], p. 123). When one of his companions tells him that they are crossing "Walna Scar" ([1], p. 124), a landmark in the Lake District, for Snitter this means that they are "walking across his own head" ([1], p. 124). Snitter's misinterpretations of his environment reach their apex when he finds himself locked in a barn:

After the first shock of surprise it was plain enough to Snitter where he was, for after all he had known the place all his life, every feature of it. Once it had been brighter, tidier, cleaner, brisker-smelling. All the same he was, in fact, nowhere but where he had always been; only now he was actually seeing it for the first time. He was inside his own head. ([1], p. 211)

Snitter's conviction again originates from an association of his scar and his environment-there is a "concave cleft running down the middle of the [barn] floor" ([1], p. 212). Analyzing his state of mind by an inspection of the barn, he finds plenty of equivalents between the dismal state of the place and the one of his mind, such as "cobwebs" in his "eyes", ([1], p. 212), and "maggots and flies" ([1], p. 212) in his brain. The overall emptiness of the place convinces Snitter that "the whitecoats must have taken some of the inside of my head out" ([1], p. 213), and provides him with ample evidence to confirm his madness. He even starts some feeble efforts to clean up his mind by brushing off some 
cobwebs ([1], p. 212). Although Snitter misreads his environment and thus bases his assumptions on false premises, every single one of his conclusions is correct. He may misinterpret his surroundings, but he does not misregard their implications. Snitter cannot explain what happened to him in the lab, but the surgery did indeed remove functions of his brain and muddle his senses. Snitter, thus, again proves to be metaphorically reliable, a central one of Phelan's categories of bonding unreliability.

Yet, there is an estranging element to Snitter's overall bonding unreliability. As an effect of his confusion between his mind and the outside world, Snitter holds himself responsible for the dismal state of the world as such, and is soon convinced that "everything bad comes out of [his] head" ([1], p. 185). He even starts to believe that, as the world is a fragment of his imagination, he can control it. In consequence, he relates story elements such as him "caus[ing] [a gate] to

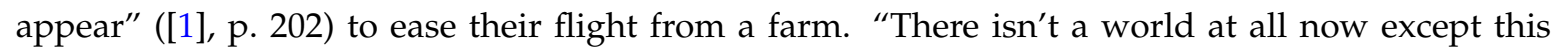
wound in my head" ([1], pp. 185-86), he tells Rowf, "if I can die and stop it all, then I'll stay here and do that. But perhaps I've died already. Perhaps dying-perhaps even dying doesn't stop it" ([1], p. 186). Snitter's fears are a one-to-one reflection of the situation Golding's Pincher Martin is in: dead and caught in a nightmare created by his own subconscious. This intertextual link casts doubt onto the very nature of Snitter's unreliability. Pincher Martin is never more unreliable than when he appears to be reliable, and his wildest hallucinations are his most reliable moments. If Snitter is indeed a canine Pincher Martin, this would render unreliable the entire physical parameters of the story, such as its setting or its character cast. Do the dogs ever leave the research station or is the entire Lake District adventure just another hallucination of Snitter's? Does Rowf really survive his near-death experience in the first scene of the story? Snitter might be merely imagining the presence of his friend. In this light, other unreliable instances of Snitter's narration-such as his frequent perception that elements of the landscape are talking to him (e.g., [1], pp. 118, 232, 430), or his sudden doubts of parts of the narration previously perceived as reliable ([1], p. 390) — can be read in entirely different dimensions. All that happens may be nothing but a complex allegory unravelling itself in the canine narrator's mind.

The reader is left with two distinct and incompatible versions of Snitter: an "obvious" Snitter driven insane by human cruelty, yet fully aware of his own madness, and characterized by bonding unreliability throughout the story, and a Pincher-Martin-Snitter whose fits of madness might be the story's only moments of sanity. Snitter's unreliable narration may thus be bonding on an overt level, but it is covertly estranging. This estrangement does not derive from any form of misreading, misinterpreting or misevaluating that can be explicitly pinpointed in Snitter's narration, but from an unreliability inherent to the very mode of unreliable narration in The Plague Dogs, ultimately inducing the implied reader to mistrust virtually any narrative account of Snitter's, as the comparison to Pincher Martin and his utterly distorted world view continuously haunts the borders of the implied reader's vision. While the animal protagonists thus find themselves helpless and confused on the story level, unreliability serves to reflect this impression to the reader on the level of discourse. Utterly confused by the inability to classify which accounts of Snitter's indeed are the unreliable ones, the reader can share the dogs' mounting desperation in being unable to cope with a world whose basic parameters do not make sense to them.

There is a further and even more diffuse twist to the estranging Pincher Martin trope. At the very beginning of the novel, it is not "Pincher Martin" character Snitter who finds himself drowning and miraculously surviving, just as Golding's protagonist does. It is his companion Rowf. This scene indicates Rowf, not Snitter, as the story's "canine Pincher Martin." Throughout almost the entire story Rowf appears as a reliable observer, and shows little evidence of fits of apparent madness such as the ones haunting Pincher Martin and Snitter. Yet there are some instances that also call into question his perception of his surroundings. At one point, he relates to Snitter his conversation with a mouse ([1], p. 63)—while the dogs, in general, do not appear to have the ability to communicate with other species. The mouse only ever reappears as an imaginary friend of Snitter's, talking in the terrier's mind (e.g., [1], pp. 52, 413). Rowf also dreams up his ideal master ([1], pp. 141-42), only to finally find himself rescued by a man fitting his description to the letter, even voicing the very 
words Rowf imagined his ideal master to speak ([1], pp. 142, 446). This third layer of unreliability adds another estranging element to the apparently bonding unreliability of the two dog characters. Both Rowf and Snitter might be far more unreliable than the implied reader can pinpoint, yet at no point in the story can the reader be sure about the nature or the extent of that unreliability. Such an entire lack of narrative stability is perhaps the most pervasive form of estranging unreliability there is. There always is a reliable element in knowing a narrator to be unreliable. Yet, if the implied author refuses this certainty to the reader, the only option left is speculation-and suspicion.

\section{Undermining Anthropocentric Normativity: The Voice of the Heterodiegetic Narrator}

An overt heterodiegetic narrator is generally a reliable voice that balances the accounts of unreliable focalizers and provides the reader with knowledge the characters do not have access to. In The Plague Dogs, however, episodes of zero focalization related by the voice of the overt heterodiegetic narrator do not reduce, but add to the "clash between story and discourse" ([11], p. 898) that renders Adams's dog story so unusual to its genre. Collado Rodriguez classifies the narrator as "menippean" ([14], p. 52), i.e., satirical, and attributes to him "a restlessness based on his satirical purpose" ([14], p. 52). Indeed, the implied reader most often encounters the narrator as a sarcastic voice commenting on the plot from the off, unveiling, and aggressively attacking a thoroughly anthropocentric superstructure that the protagonists themselves are oblivious of. He is fiercely protective of the dogs, sometimes to the point of underreporting or misreporting story elements in their favour.

One central aim of the narrator's satire is science, or more precisely the hypocrisy inherent to the rationalist ethos of science and to the respective discourse tradition. For example, the narrator describes an experiment on homing pigeons in the following terms:

One could draw the firm and valuable conclusions first, that birds whose faculties had been impaired were less swift and competent in getting home than birds whose faculties had not; and secondly, that in any given group, some succeeded in returning while others, who did not, presumably died. ... Important evidence had been obtained in support of the theory that the birds possessed an instinct not really explicable in scientific terms. ([1], p. 28)

In this text passage, the narrator turns the discourse of science against itself. In its use of scientific register, the passage provides the illusion of rationality, but the final phrase unmasks the objective-descriptive enumeration of "valuable" scientific conclusions as an elaborate hoax. While scientific discourse creates sophisticated bubbles of rationalist rhetoric, it is incapable of narrating the story of the homing pigeons. The reader thus finds herself confronted with a clash of reason and instinct, of stereotypical human vs. stereotypical animal domains. Only instinct can tell the story, while reason is nothing but discourse caught in a vicious circle of continuous self-affirmation. The laughter triggered by the narrator's satire is the very same laughter of the Bakhtinian carnival. ${ }^{4}$ An "ambivalent" ([18], p. 53) laughter directed towards a recipient so powerful as to be out of reach of direct criticism, but who can be parodied and even ridiculed in "the suspension of restrictions and hierarchies" ([19], p. 16) brought about by carnival celebrations. In the medieval practices Bakhtin derives his concept of the carnivalesque from, such a powerful entity parodied in carnivalesque laughter might have been the king, or God ([18], p. 54). In The Plague Dogs, the laughter targets the rationalist ethos of science that, in the ideological framework of contemporary Western cultures, often reaches quasi-religious dimensions. Similar passages attack other central pillars of modern

4 Bakhtin builds his concept of the carnivalesque upon the power-subverting practices of Medieval European and ancient Greek carnival festivities ([18], p. 47). As the metaphoric language of literature shares the symbolic power of carnival festivities, he sees these practices reflected in the genre of the novel ([18], p. 47). This link, arguably, is even stronger when the novel at hand is one that undermines power hierarchies in its very narrative structure, as does a novel granting a central voice and most of its narrative space to non-human protagonists. As Catherine Elick states, a Bakhtinian reading is therefore a particularly useful approach for "confronting the ideology undergirding species valuation" ([19], p. 3). 
scientific ethos, such as scientific detachment ([1], p. 18), the allegedly noble nature of scientific curiosity as an end to itself ([1], p. 18) or "benefit for the human race" ([1], p. 128) as the ultimate justification for animal experimentation. With regard to all these, discourse turns into an empty shell, unable to tell the story of both human and animal protagonists, or sometimes telling a story that is not true. When the narrator exuberantly praises the lab's head scientist as a "most ingenious paradox, noble in reason, express and admirable in action, his undemonstrative heart committed with the utmost detachment to the benefit of humanity. Something too much of this" ([1], p. 18), the reader can only glimpse the story in the flippant afterthought.

Throughout the novel, the heterodiegetic narrator champions the voice of literature over the voice of science. The reader gets to know the narrator as a highly educated, at times even lyrical storyteller who is able to draw inspiration from virtually the entirety of the Western intellectual canon. He quotes Shakespeare ([1], p. 455) and Dr. Johnson ([1], p. 169), casually refers to Freud ([1], p. 16) and to the muse Urania ([1], p. 200), or imitates the writing style of James Joyce ([1], p. 421). However, he does not only make use of these pretexts to transmit his own message, as would be the standard use of intertextual reference, but shows up the shortcomings of the discourse of "literature" in a similar way to his dismantling of the discourse of science. In the first scene of the story, for example, the narrator describes a tank fouled with urine and saliva in which at that very moment Rowf is fighting for his life. The surface is "a watery harlequin's coat of tilting planes and lozenges in movement" ([1], p. 1), the "streaks of urine" are "gilded" ([1], p. 1), and bubbles of saliva are rocking "turgidly" ([1], p. 1). In this description, the implied reader realizes a gap not between narrator and implied author, but in the narrator's discourse itself: a gap between the tenor and the vehicles of metaphors. The narrator's language is the language of "literature," but, as does the empty discourse of science, the high register and metaphorical complexity of literature does not unveil reality, but glosses over the sufferings of Rowf, who, pointedly, in this scene is refused both agency and a voice. In presenting as an epitome of beauty what is in fact a hideous reality, the narration reverses Phelan's bonding unreliability category of "literally unreliable but metaphorically reliable" ([9], p. 226) narration. The narrator is literally reliable but metaphorically unreliable, and as intellectual convention has long taught the reader to consider the metaphorical level the apex of literary language, and to trust it above all others, this creates a substantial gap between narrator and reader.

The narrator thus places the reader in a paradoxical situation. On the one hand, the 'literariness' of the narratorial voice of The Plague Dogs demands the reader to be well-versed in the conventions of literary discourse, and challenges every lack of knowledge of the literary canon. When the narrator recounts the reunion between Snitter and his master, for example, it is the reader's own task to notice the moment when the narrator stops relating the events, and instead leaves this to Shakespeare: "Forgive me-I make a broken delivery of the business on the sand-dunes at Drigg. I never heard of such another encounter: a sight which was to be seen, but cannot be spoken of. They looked as they had heard of a world ransomed, or one destroyed" ([1], p. 455; see also [20], 5.2,14-15). On the other hand, the narrator constantly undermines the conventions of literature, highlighting that literature too can become an instrument of anthropocentric hegemony, and even more tragically so than the rationalist story-deprived discourse of science. Literature indeed can and does tell stories, yet these stories might trick the reader into averting the eyes from the animal. Still, the narrator's voice shows far more respect for the discourse of literature than for the one of science. The literary, so the narrator's implicit indication, is a discourse that can indeed be compatible with "instinct." In the environment of the literary, the animal might be capable not only of telling its own tale, but even of being listened to by a human audience-if the animal is granted a voice.

Collado Rodriguez describes the narrator as "a very playful and restless figure in the fashion of Tristram Shandy" ([14], p. 51). Yet while the narrator of Tristram Shandy is satirical, omnipresent, and "enthral[ling]" ([10], p. 8), i.e., in Phelan's terminology, has a bonding effect on the reader, the narrator of The Plague Dogs is virtually erratic. This unpredictability often has an estranging effect. During long parts of the text the narrator fades away to a covert voice reporting the dogs' 
journey, describing the landscape, or relating Snitter's thoughts to the reader. At unpredictable intervals, however, this voice suddenly turns overt, voicing sarcastic, impolite, or downright rude comments. The narrator interrupts an almost lyrical passage on Snitter howling to the moon to attack Mediterranean hunters shooting migratory birds as "hirsute swine[s]" ([1], p. 260), expresses disappointment that no one took the chance to murder a particularly unpleasant one of his characters ([1], p. 200), or directly targets the reader, threatening that there will be a "price to pay" ([1], p. 192) for the "unnatural"' way of life of modern Western civilisation. Towards the end of the story the implied reader notices that the narrator previously purposefully withheld information to manipulate the reader's perspective on animal experimentation. The narrator waits for the final pages to disclose the motivation that drove one of the scientists to work in the lab: Mr. Powell searched for a cure for his young daughter, who is dying of cancer ([1], p. 449). At the point of this disclosure the implied reader, having been given an entirely animal-focused view on animal experimentation for more than four hundred pages of dense tragedy, will find herself stupefied by the very notion that there indeed is a different perspective - that there might be justifications for the practice the narrator has carefully taught the reader to abhor. Notably, the reader only learns about Mr. Powell's incentive after the scientist has changed his mind, and despite his daughter's illness, has decided to not only quit his job but even to illegally free an animal from the lab. In fact, the reader is only allowed to hear Mr. Powell's voice after he switched to the discourse the narrator presents as the correct one.

Most unreliable about the heterodiegetic narrator, however, is the narrative style. Style changes constantly, from prose to poetry ([1], p. 421), or from colloquial language to biblical language and back ([1], p. 317). In consequence the reader can never know which kind of narration she is to encounter in the next line. After the dogs killed their first sheep, for example, Snitter elapses into rhyme, as he sometimes does in his mad moments, and the narrator immediately joins in:

Incrimination and heady elation, cutting capers in the misty vapours, havoc and ravage hurrah for the savage life precarious, life so various, life nefarious and temerarious, pulling faces, fierce grimaces, leaving traces in rocky places, pieces and faeces all over the fleece is that a yow's shoulder they've left there to moulder stuck up on a boulder? Much to learn, Rowf, in the fern, of great concern, for this is the point of no return. Those who kill sheep should mind where they sleep...([1], p. 76)

On the content level this narration is reliable, but not on the level of discourse. The reader is left at a loss whether the narrator is just reflecting Snitter's state of mind, or might be affected by the madness himself. Episodes casting doubt onto the narrator's sanity become more frequent towards the end of the narrative, when, at times, the narrator appears to be virtually rambling:

Along the estuary we go, black-and-white oyster-catchers flashing rapid, pointed wings... and an old heron flapping slowly away by himself. Can that be the tod [character killed in a fox hunt] I see, with Kiff [character killed in the lab], up on a cloud? No, I beg your pardon, must have got some hairspray in my eyes [as in a lab experiment on rabbits], but let's raise a cheer all the same. Never again, hide in a drain, ride in a train, died in the rain—it's not raining yet, anyway. ([1], p. 423)

The heterodiegetic narrator's fits of apparent madness, even more unpredictable than Snitter's ones, create the impression of a voice driven insane by the sufferings of the characters whose plight it reports. This voice, crucially, is human, not animal, yet it frequently focalizes through animal eyes and grants narrative space to the non-human. Shaping its discourse around the dogs and their perception of the world, the narrator's voice-unlike the empty discourse of science-proves to be able to tell the canine heroes' story. Moreover, its erratic unreliability intensifies the story, giving powerful expression to a form of animal suffering normally happening in silence and well outside the implied reader's line of vision. This suffering, once granted a voice, is so intense as to break the structural constraints of discourse. Unreliable narration in The Plague Dogs thus dismantles an uncomfortable 
truth: traditional forms of narration can only uphold their alleged reliability by means of averting the reader's attention from non-human stories. The heterodiegetic narrator's unreliability in The Plague Dogs in consequence does not seek to estrange the implied reader from the narrator, but from the set of values which render this narration unreliable. Instead of undergoing a "partial progress towards the norm" ([9], p. 231) the narrator seeks to raise the reader's awareness of the problematic dimensions of the norm. In the end, the reader is left with only a single reliable set of facts: the dogs are suffering, and by means of accepting the shared values, and especially the evasive discourse of the society causing this suffering, the implied reader, too, bears her share of the blame.

\section{The Reader Shipwrecked: Unravelling the Ending}

When considered from the perspective of narratorial discourse, The Plague Dogs appears entirely open-ended. On the face of it, the story has a typical happy ending: in a miraculous rescue, two naturalists save the dogs from drowning, and the two long-suffering canine heroes can start a new life with Snitter's former master who suddenly turns out to be alive after all. This ending was under criticism for undermining the serious political intention of the story, e.g., by reviewer Naomi Wise, who censured it as "spurious" ([21], p. 54). But the moment a reading of the ending takes into account the complex interplay of narrative unreliabilities, the final scenes of The Plague Dogs can also be approached as yet another twist on the Pincher Martin trope. Pincher Martin believes that he finds himself miraculously rescued from drowning, while he, in fact did drown. Therefore, he is at his most unreliable when he appears to be reliable-only his hallucinations call into question his account of his island survival. The Plague Dogs, in addition to starting with Rowf drowning, ends when the dogs find themselves miraculously rescued from drowning again. However, they, in contrast to Pincher Martin, believe they are dead now. If this were a homodiegetic account by Snitter, or, as the plotline of Pincher Martin, a heterodiegetic internally focalized account of Snitter, and Snitter only, the reader could indeed come to the conclusion that Snitter is dead and dreams up a walk through a watery purgatory that finally ends in his accepting his death, and entering dog heaven at the side of his (equally dead) master.

But the heterodiegetic narrator balances Snitter's account and continually anchors it in reality. Several of the previous plotlines come together, and the narrator's zero focalisation allows different protagonists' views to throw light on the scene, while all of these views add up to one logical narrative. Indeed, if it had not been for the previous erratic behaviour of the heterodiegetic narrator and the recurrent Pincher Martin allusions, a reader probably would not doubt this ending for a second. But, taking into account both of these aspects, one can read the ending as a final twist to the story, and even to the Pincher Martin-trope. At the end of Pincher Martin, the implied reader learns for sure that she has fallen victim to an entirely distorted view on the story's reality. At the end of The Plague Dogs, in contrast, the reader is left at a total loss whether to consider the "happy ending" scene as reliable or unreliable. There are some unreliability markers, such as the one-to-one correspondence between Rowf's ideal master and naturalist Peter Scott, and the overall too-good-to-be-true quality of both the action and the characters' dialogue. This dialogue, in an additional twist, even projects unreliability beyond the text itself, and purposefully undermines not only the narrator's reliability, but even the one of the author. Ronald Lockley, fictional counterpart of a real and renowned naturalist, dismisses Richard Adams as "hopelessly sentimental" ([1], p. 440), thus attributing to him a bias that obviously cannot but colour the tenor of the entire narrative. Yet none of these puzzles of unreliability are resolved in any way comparable to Golding solving Pincher Martin's mystery by suddenly shifting the narratorial focus from the unreliable Pincher Martin to two reliable characters ([17], p. 202).

The Plague Dogs, in consequence, offers two distinct readings of its ending. If the heterogetic narrator is reliable, this is a happy ending, and a very genre-typical one as well. The plot line has shown that there are indeed bad humans out there, doing terrible things to animals in their ruthless anthropocentrism and egocentrism. The ending however blends this with hope: such humans can be overcome, as long as there are some fine specimens of humanity who are willing to fight for animals. 
If the heterodiegetic narrator is unreliable, in contrast, the ending is a tragedy. The narrator gives up on what Rowf repeatedly classifies as "a bad world for animals" ([1], p. 23). Just like Snitter in the newspaper story, the narrator relates a fairy tale, something that in another world, once upon a time, might have taken place, but can never happen in reality. If one chooses this reading, one can even pinpoint the exact moment when the narrator gives up on the madness of the situation, and instead employs talking animal story stock elements. This is the moment Snitter drowns:

No feeling in the legs. Cold. Cold. Longing to rest, longing to stop, losing two gasps in every three for a lungful of air. The stinging, muzzle-slapping water, rocking up and down. This isn't a dream. It's real, real. We're going to die. ...Cold. Sinking. Bitter, choking dark. ([1], p. 438)

Collado Rodriguez calls this "the logical end of the novel" ([14], p. 52), describing the following happy ending as a "metafictional element" ([14], p. 53), a claim that I would second. Perhaps, one could best describe the ending as an escapist fantasy of a narrator who tries and ultimately fails to apply patterns that make sense to a world that does not. Such patterns are ubiquitous in the novel, most prominently in form of Carl Gustav Jung's theory of the collective unconscious, and Joseph Campbell's hero's journey that leads the heroes on a "flight... complicated by marvels of magical obstruction and evasion" ([8], p. 197). But these patterns reach their limits once the literary animal appears as animal. What happens to Joseph Campbell's hero if his final reward is denied to him because of his species? How does the Jungian unconscious function if there is no rationalistic Western human consciousness to balance the primitive, instinctive nature of the unconscious, but a canine one? The narrator does not seek to answer these questions, but pushes them until they become deeply disconcerting for the implied reader-only to abruptly revert to an easier mode of story-telling at the very moment the reader might be seriously considering the dimensions the answers might reach. This again calls to mind Phelan's category of "partial progress towards the norm" ([9], p. 231) as a bonding category. In the final scene of The Plague Dogs, the heterodiegetic narrator does the opposite: he seeks to undermine and, eventually, in the double-edged happy ending, to destroy the norm itself. This is estranging and unsettling, uncanny, even, but ultimately seeks to open readers' eyes to the issue at hand: the hopeless situation of animals in the madhouse of Western civilization. The world the story presents (our own world, satirically overdrawn, but metaphorically reliable) is so ludicrous that sanity does not stand a chance, and all well-worn patterns that seek to introduce some order to the chaos appear to exclude the animals who are the heroes of the story.

Escaping reality, indeed, might be the only coping mechanism for an animal narrator caught in the world of The Plague Dogs. Snitter does in his hallucinations. Rowf does in finally entering the magical world of Snitter's happy-pet fairy tale when he believes himself in dog heaven ([1], p. 452). The narrator does, too, if indeed he makes up a happy ending after the dogs drowned. Is the narrator a coward, then? "Yes" might be the implied reader's simple answer-and here we suddenly find ourselves looking through the eyes of Snitter, facing his anima on the moors, shouting the truth into her face, and never realizing that it is his truth, not hers. The reader is finally left to make her own decision if she wants to follow the narrator's solution of playing-ostrich, or if she dares to read the animal protagonists as animals, and in doing so to face the insanity underlying Western culture's tradition of anthropocentrism and self-deception.

Conflicts of Interest: The author declares no conflict of interest.

\section{References}

1. Richard Adams. The Plague Dogs. Harmondsworth: Penguin Books, 1977.

2. Nicholas Wade. “Briefing: A New Militancy in England." Science 199 (1978): 279. [PubMed]

3. “Are Dogs Moral? Do Horses Have Souls? " The Hastings Center Report. Available online: www.jstor.org/ stable/3562679 (accessed on 12 February 2017).

4. Theodore Ziolkowski. Varieties of Literary Thematics. Princeton: Princeton University Press, 1983. 
5. Colin Manlove. The Fantasy Literature of England. Basingstoke: Macmillan, 1999.

6. Alison Flood. "Watership down Author Richard Adams: I just Can't Do Humans." Available online: www.theguardian.com/books/2015/jan/04/richard-adams-watership-down-interview (accessed on 19 December 2016).

7. Carl Gustav Jung. Die Archetypen und das kollektive Unbewusste. Olfen: Walter-Verlag, 1976.

8. Joseph Campbell. The Hero with a Thousand Faces. Princeton: Princeton University Press, 1968.

9. James Phelan. “Estranging Unreliability, Bonding Unreliability, and the Ethics of Lolita." Narrative 15 (2007): 222-38. [CrossRef]

10. Wayne C. Booth. The Rhetoric of Fiction. Chicago and London: The University of Chicago Press, 1961.

11. Dan Shen. "Unreliability." In Handbook of Narratology. Edited by Peter Hühn, Jan Christoph Meiser, John Pier and Wolf Schmid. Berlin: De Gruyter, 2014, pp. 896-909.

12. James Phelan. Living to Tell About It: A Rhetoric and Ethics of Character Narration. Ithaca and London: Cornell University Press, 2005.

13. Gérard Genette. Die Erzählung. Paderborn: Fink, 2010.

14. Francisco Collado Rodriguez. "Beyond Satire: Richard Adams's The Plague Dogs." The International Fiction Review 15 (1988): 51-53.

15. Xiaoming Wang, and Richard H. Tedford. Dogs: Their Fossil Relatives and Evolutionary History. New York and Chichester: Columbia University Press, 2008.

16. Anja Höing. "'Snit's a Good Dog!' Innate Duty in Richard Adams's The Plague Dogs." In Who's Talking Now: Multispecies Relations from Human and Animals' Point of View. Edited by Chiara Blanco and Bel Deering. Oxford: Interdisciplinary Press, 2015, pp. 69-76.

17. William Golding. Pincher Martin. London: Faber \& Faber, 1973.

18. Michaeil M. Bachtin. Literatur und Karneval. Zur Romantheorie und Lachkultur. Frankfurt am Main: Fischer, 1990.

19. Catherine L. Elick. Talking Animals in Children's Fiction. A Critical Study. Jefferson: McFarland \& Company, 2015.

20. William Shakespeare. The Winter's Tale. The Arden Shakespeare; Edited by J.H.P. Pafford. London: Thompson Learning, 1999.

21. Naomi Wise. “Review: The Plague Dogs.” Film Quarterly 38 (1985): 53-54. [CrossRef] 